\title{
THE DIVERSITY, EXTRACELLULAR ENZYMATIC ACTIVITIES AND PHOTOPROTECTIVE COMPOUNDS OF YEASTS ISOLATED IN ANTARCTICA
}

\author{
Aline B. M. Vaz ${ }^{1}$, Luiz H. Rosa ${ }^{1}$, Mariana L. A. Vieira ${ }^{1}$, Virginia de Garcia ${ }^{2}$, Luciana R. Brandão ${ }^{1}$, Lia C. R. S. Teixeira ${ }^{1}$, \\ Martin Moliné2, Diego Libkind², Maria van Broock ${ }^{2}$, Carlos A. Rosa ${ }^{1^{*}}$ \\ ${ }^{1}$ Departamento de Microbiologia, Instituto de Ciências Biológicas, Universidade Federal de Minas Gerais, Belo Horizonte, MG, \\ Brasil; ${ }^{2}$ Laboratório de Microbiología Aplicada y Biotecnología, Instituto de Investigaciones en Biodiversidad y Medio Ambiente, \\ Universidad Nacional del Comahue-CONICET, Bariloche, Argentina.
}

Submitted: October 27, 2010; Approved: January 13, 2011.

\begin{abstract}
The diversity of yeasts collected from different sites in Antarctica (Admiralty Bay, King George Island and Port Foster Bay and Deception Island) and their ability to produce extracellular enzymes and mycosporines were studied. Samples were collected during the austral summer season, between November 2006 and January 2007, from the rhizosphere of Deschampsia antarctica, ornithogenic (penguin guano) soil, soil, marine and lake sediments, marine water and freshwater from lakes. A total of 89 isolates belonging to the following genera were recovered: Bensingtonia, Candida, Cryptococcus, Debaryomyces, Dioszegia, Exophiala, Filobasidium, Issatchenkia (Pichia), Kodamaea, Leucosporidium, Leucosporidiella, Metschnikowia, Nadsonia, Pichia, Rhodotorula, and Sporidiobolus, and the yeast-like fungi Aureobasidium, Leuconeurospora and Microglossum. Cryptococcus victoriae was the most frequently identified species. Several species isolated in our study have been previously reported to be Antarctic psychophilic yeasts, including Cr. antarcticus, Cr. victoriae, Dioszegia hungarica and Leucosporidium scottii. The cosmopolitan yeast species A. pullulans, C. zeylanoides, D. hansenii, I. orientalis, K. ohmeri, P. guilliermondii, Rh. mucilaginosa, and S. salmonicolor were also isolated. Five possible new species were identified. Sixty percent of the yeasts had at least one detectable extracellular enzymatic activity. Cryptococcus antarcticus, D. aurantiaca, D. crocea, D. hungarica, Dioszegia sp., E. xenobiotica, Rh. glaciales, Rh. laryngis, Microglossum sp. 1 and Microglossum sp. 2 produced mycosporines. Of the yeast isolates, $41.7 \%$ produced pigments and/or mycosporines and could be considered adapted to survive in Antarctica. Most of the yeasts had extracellular enzymatic activities at $4^{\circ} \mathrm{C}$ and $20^{\circ} \mathrm{C}$, indicating that they could be metabolically active in the sampled substrates.
\end{abstract}

Key words: yeasts; Antarctica; diversity; extracellular enzymes; mycosporines.

\footnotetext{
*Corresponding Author. Mailing address: Departamento de Microbiologia, Instituto de Ciências Biológicas, Universidade Federal de Minas Gerais, Belo Horizonte, MG, Brazil.; E-mail: carlrosa@ @icb.ufmg.br
} 


\section{INTRODUCTION}

The continent of Antarctica has a range of extreme climatic conditions and is considered to be one of the harshest ecosystems in the world. The low temperature, low water availability, low annual precipitation, frequent freeze-thaw cycles, strong winds, high sublimation and evaporation, and the high incidence of solar and especially ultraviolet radiation are significant limiting factors for plant and animal life in Antarctica (8). In addition, the geographic isolation and environmental stress make interesting the study of its endemic organisms (34). Recently, the occurrence and diversity of fungal species in this region has been investigated $(2,13,32$, 33, 34). According to Ruisi et al. (34), most of the fungi recorded in this area are anamorphic, have short life cycles, and limit metabolic costs associated with sexual reproduction. More than 1,000 fungal species have been reported from the maritime, continental, and sub-Antarctic regions $(6,29)$.

Yeasts are able to grow at the low temperatures of Antarctica, suggesting that they are capable of degrading organic compounds at these temperatures and being an active part of the nutrient cycle $(1,36)$. Most yeast species of Antarctica are basidiomycetous anamorphs, but ascomycetous species may also be endemic to Antarctic habitats $(23,37,40)$. The adaptation of these yeasts to cold habitats is also reflected in their structural and biochemical characteristics (37). The production of cold-adapted enzymes, cryoprotectants, and high amounts of polyunsaturated fatty acids in cytoplasmic membranes are examples of these adaptive strategies (40). In addition, the production of photoprotective compounds (carotenoids and mycosporines) by yeasts could be a strategy to survive in extreme environments. Mycosporines are watersoluble, UV-absorbing (310-320 nm) compounds with an aminocyclohexenone unit bound to an amino acid or amino alcohol group (21). The production of these compounds in yeasts from high-altitude lakes exposed to increased UV radiation has been correlated with the survival of some species in these environments (22). The photoprotective role of mycosporines, particularly mycosporine-glutaminol-glucoside, in yeasts as UV protectants and antioxidants has recently been reported (28). Carotenoids function primarily as antioxidants, and their UV-protective role has been also demonstrated in yeasts $(26,27)$.

Here, we describe the isolation and identification of yeast species present in the rhizosphere of the grass Deschampsia antarctica Desv. (Poaceae), ornithogenic (penguin guano) soil, soil, water from lakes, seawater and sediments collected from different locations in Admiralty Bay at King George Island and Port Foster Bay at Deception island, Antarctica. In addition, we tested the ability of these yeasts to produce extracellular enzymes and mycosporines.

\section{MATERIALS AND METHODS}

\section{Sampling sites and collections}

The samples were collected at different sites in the Antarctic Specially Managed Area (ASMA) in Admiralty Bay, King George Island, South Shetland Islands (6209'S, $\left.58^{\circ} 28^{\prime} \mathrm{W}\right)$ and Port Foster Bay, Deception island (62 $55.5^{\prime} \mathrm{S}$, $\left.60^{\circ} 37^{\prime} \mathrm{W}\right)$, Antarctica. Fourteen collection sites were selected along Admiralty Bay and Port Foster Bay (Table 1), and all were sampled during the austral summer season between November 2006 and January 2007. Samples were collected from the rhizosphere of Deschampsia antarctica Desv. (Poaceae) (21 samples), ornithogenic (penguin guano) soil (8 samples), soil (11 samples), marine (4 samples) and lake (3 samples) sediments, marine water (5 samples) and lake freshwater (16 samples). The samples were collected with sterile bags (roots, sediments, and soils) or sterile bottles (seawater and freshwater) and transported to the laboratory on ice within $24 \mathrm{~h}$ for processing. Marine sediment samples were collected using a Van Veen grab at depths not exceeding $60 \mathrm{~m}$ and stored at $4^{\circ} \mathrm{C}$ until use, not exceeding $24 \mathrm{~h}$.

\section{Yeast isolation}

Water from each site $(10 \mathrm{~mL})$ was filtered through 0.45 - 
$\mu \mathrm{m}$ membranes with a 47-mm diameter (Millipore, USA). The membranes were placed on YM agar $(0.3 \%$ yeast extract, $0.3 \%$ malt extract, $0.5 \%$ peptone, $2 \%$ glucose, $2 \%$ agar) containing $100 \mathrm{mg} \mathrm{mL}^{-1}$ chloramphenicol (Sigma, USA) and incubated at $15^{\circ} \mathrm{C}$ for 15 days. To obtain yeasts from soil, sediment, and the rhizosphere of $D$. antarctica, $1 \mathrm{~g}$ of each sample was added to $9 \mathrm{~mL}$ of Hanks buffer (Sigma, USA), and $100-\mu \mathrm{L}$ serial dilutions $\left(10^{-1}\right.$ and $\left.10^{-2}\right)$ were inoculated onto YM agar plates and incubated as above. The different yeast morphotypes were counted, purified and maintained on YM agar slants or liquid nitrogen for later identification. All yeast isolates were deposited in the Collection of Microorganisms and Cells of the Universidade Federal of Minas Gerais.

\section{Yeast identification}

The yeasts were characterized by standard methods (41), and identifications followed the keys of Kurtzman and Fell (17). Isolates with identical morphological and physiological characteristics were grouped together and subjected to PCR fingerprinting using the microsatellite-primed PCR technique (MSP-PCR) with the core sequences of the phage M13 (5'GAGGGTGGCGGTTCT-3'). DNA extraction was performed according to the protocols described by Loque et al. (23). PCR was performed in a $25-\mu \mathrm{L}$ reaction containing $2.5 \mu \mathrm{L}$ of $10 \mathrm{X}$ Mg-free PCR buffer, $1.5 \mu \mathrm{L}$ of $25 \mathrm{mM} \mathrm{MgCl}_{2}, 1 \mu \mathrm{L}$ of $2 \mathrm{mM}$ deoxyribonucleotide triphosphates (dNTPs), $1 \mu \mathrm{L}$ of each 10 $p \mathrm{~mol}^{-1}$ of M13 primer, $5 \mu \mathrm{L}$ of DNA template, and $0.2 \mu \mathrm{L}$ of 1 U/ $\mu \mathrm{L}$ Taq DNA polymerase (Fermentans, USA). The PCR was performed according to Libkind et al. (20). Isolates with identical DNA banding patterns were grouped and considered to belong to the same species $(14,35)$.

The internal transcribed spacer (ITS) and D1/D2 domains of the large subunit rRNA gene were sequenced in a representative strain of each MSP-PCR group. The D1/D2 domains were PCR-amplified with primers NL1 (5'GCATATCAATAAGCGGAGGAAAAG-3') and NL4 (5'GGTCCGTGTTTCAAGACGG-3') according to Lachance et al. (19). The ITS domains of the rRNA gene were amplified using the universal primers ITS1 (5'-TCCGTAGGTGAACC TGCGG-3') and ITS4 (5'-TCCTCCGCTTATTGATATGC-3') as described by White et al. (42). ITS-amplification and sequencing protocols were performed as described by Vaz et al. (39). The amplified DNA was concentrated and cleaned using Wizard Plus SV columns (Promega, USA), and sequenced in a MegaBACE ${ }^{\mathrm{TM}} 1000$ automated sequencing system (GE Healthcare, USA). The consensus sequence data were aligned with all sequences of related species in the GenBank database using Fasta 2.0 (3). The obtained nucleotide sequences and related sequences were aligned using ClustalW (http://www.ebi.ac.uk/clustalw/), and phylogenetic relationships were estimated using MEGA version 2.1 (16).

\section{Extracellular enzymatic activity}

All yeasts were tested for their ability to degrade starch, protein (casein), lipids (trybutirin and Tween-80), pectin and cellulose according to procedures described by Brizzio et al. (5). Calibrated suspensions of $10^{6}$ cells $\mathrm{mL}^{-1}$ grown for $24-48 \mathrm{~h}$ were inoculated $(10 \mu \mathrm{L})$ on the surface of agar plates (9). Plates containing each substrate were incubated at $4^{\circ} \mathrm{C}$ or $20^{\circ} \mathrm{C}$. Enzymatic activity was analyzed after 5 days in samples incubated at $20^{\circ} \mathrm{C}$ and after 21 days in those incubated at $4^{\circ} \mathrm{C}$. The halo/colony $(\mathrm{h} / \mathrm{c})$ ratio was used as a semi-quantitative assessment of extracellular enzymatic activity. Sporobolomyces ruberrimus CRUB1141 (amylase), Leucosporidiella fragaria CRUB1211 (protease), Rhodotorula mucilaginosa CRUB138 (lipase and pectinase) and Trichosporon mycotoxinivorans UFMG-HB20 were used as positive controls for enzymatic activities. Data for both temperatures were statistically compared using Student's $t$-test (9).

\section{Production of photoprotective compounds}

Mycosporine detection, extraction, and induction were analyzed as described by Libkind et al. (21). Briefly, the isolates were incubated for 4 days at $18^{\circ} \mathrm{C}$ in an environmental 
test chamber (Sanyo MLR 350) with a 12:12 light:dark photoperiod. The chamber was illuminated with 10 white light fluorescent tubes (Sanyo, 40W) and 5 Q-Panel 340 fluorescent tubes, resulting in photosynthetically active radiation (PAR), UVA and UVB irradiances of 66,15 , and $0.7 \mathrm{Wm}^{-2}$, respectively. For the screening analysis, isolated colonies were shielded with Ultraphan-395 film (UV Opak, Digefra, Munich, Germany, cutoff: $395 \mathrm{~nm}$ ) and exposed to PAR only. After exposure, colonies were transferred to distilled water, centrifuged and stored at $-20^{\circ} \mathrm{C}$ until mycosporine extraction. The pigment production was evaluated by the direct observation of yeast colonies grown on YMA at $5^{\circ} \mathrm{C}$ for 2 weeks.

\section{RESULTS AND DISCUSSION}

\section{Yeast diversity and identification}

The lowest yeast counts were from freshwater and seawater samples, ranging from $2 \log \mathrm{CFU} \mathrm{L}^{-1}$ (meltwater of the Copacabana Refuge Lake) to $2.54 \log \mathrm{CFU} \mathrm{L}^{-1}$ (meltwater of the Machu Picchu Station Lake) and $2 \log$ CFU L ${ }^{-1}$ (seawater of Ullmann Point) to $2.24 \log \mathrm{CFU} \mathrm{L}^{-1}$ (seawater of Botany Point). The highest counts were in soil and sediment samples (Table 1). In this work, counts in soil containing penguin guano ranged from 2 to $3 \log \mathrm{CFU} \mathrm{g} \mathrm{g}^{-1}$; ornithogenic soils may provide rich sources of organic matter. di Menna et al. (10) reported variable counts ranging from 0.69 to over 5 $\log \mathrm{CFU} \mathrm{g}{ }^{-1}$ from Antarctic soil samples. Yeasts can grow in many soil types from diverse geographical areas ranging from the arctic to the tropics $(4,18,30)$. The role of soil yeasts in terrestrial ecosystems, in particular Antarctic soils, has not been adequately explored.

A total of 89 yeast isolates were obtained and identified in following genera: Bensingtonia, Candida, Cryptococcus, Debaryomyces, Dioszegia, Exophiala, Filobasidium, Issatchenkia (Pichia), Kodamaea, Leucosporidium, Leucosporidiella, Metschnikowia, Nadsonia, Pichia, Rhodotorula, and Sporidiobolus, and the yeast-like fungi Aureobasidium, Leuconeurospora and Microglossum (Tables 2 and 3). Most were basidiomycetous anamorphs, and Cryptococcus species were the most frequently isolated yeasts in all samples. Cryptococcus species are frequently found in a variety of Antarctic sites and substrates, and many are psychrophilic (40). Cryptococcus species may be able to utilize available nutrients in oligotrophic systems, whereas most ascomycetous species cannot (7).

Table 1. Location of sampling sites and viable yeast counts isolated in different sources in Antarctica.

\begin{tabular}{|c|c|c|c|c|c|}
\hline Substrate & Sites and location & $\begin{array}{l}\text { Number } \\
\text { of } \\
\text { samples }\end{array}$ & $\begin{array}{l}\log \mathrm{CFU} / \mathrm{g} \\
\text { or } \log \\
\mathrm{CFU/L^{a }}\end{array}$ & $\begin{array}{l}\text { Mean Log } \\
\text { CFU/g or } \\
\text { CFU/L }\end{array}$ & $\begin{array}{l}\text { Standard } \\
\text { deviation } \\
\quad(\log )\end{array}$ \\
\hline $\begin{array}{l}\text { Rhizosphere of } \\
\text { Deschampsia } \\
\text { antarctica Desv. } \\
\text { (Poaceae) }\end{array}$ & $\begin{array}{l}\text { Machu Picchu Station }\left(62^{\circ} 07^{\prime} \mathrm{S}, 58^{\circ} 23^{\prime} \mathrm{W}\right) \text {; Plaza point }\left(62^{\circ} 03^{\prime} \mathrm{S} \text {, }\right. \\
\left.58^{\circ} 24 \mathrm{~W}\right) \text {; Brazilian Refuge II }\left(62^{\circ} 04^{\prime} \mathrm{S}, 58^{\circ} 25^{\prime} \mathrm{W}\right) \\
\text { Demay point }\left(62^{\circ} 12^{\prime} \mathrm{S}, 58^{\circ} 19^{\prime} \mathrm{W}\right) \text {; Hennequin point }\left(62^{\circ} 05^{\prime} \mathrm{S}, 58^{\circ} 24^{\prime} \mathrm{W}\right) \text {; } \\
\text { Botany point }\left(62^{\circ} 05^{\prime} \mathrm{S}, 8^{\circ} 19^{\prime} \mathrm{W}\right) \text {; Ulmann point }\left(62^{\circ} 05^{\prime} \mathrm{S}, 58^{\circ} 20^{\prime} \mathrm{W}\right) \text {; } \\
\text { Henry Arctowisky Station }\left(62^{\circ} 09^{\prime} \mathrm{S}, 58^{\circ} 27^{\prime} \mathrm{W}\right)\end{array}$ & 21 & $2-3.2^{\mathrm{b}}$ & 2.4 & 0.4 \\
\hline $\begin{array}{l}\text { Ornithogenic } \\
\text { (penguin guano) soil }\end{array}$ & Demay point $\left(62^{\circ} 12^{\prime} \mathrm{S}, 58^{\circ} 19^{\prime} \mathrm{W}\right)$; Chabrier Rock $\left(62^{\circ} 11^{\prime} \mathrm{S}, 58^{\circ} 18^{\prime} \mathrm{W}\right)$ & 8 & $2-3$ & 2.1 & 0.3 \\
\hline Soil & $\begin{array}{l}\text { Ulmann point }\left(62^{\circ} 05^{\prime} \mathrm{S}, 58^{\circ} 20^{\prime} \mathrm{W}\right) \text {; Henry Arctowisky Station }\left(62^{\circ} 09^{\prime} \mathrm{S} \text {, }\right. \\
\left.58^{\circ} 27^{\prime} \mathrm{W}\right) \text {; Botany point }\left(62^{\circ} 05^{\prime} \mathrm{S}, 8^{\circ} 19^{\prime} \mathrm{W}\right) \text {; Comandante Ferraz } \\
\text { Brazilian Station }\left(62^{\circ} 05^{\prime} \mathrm{S}, 58^{\circ} 24^{\prime} \mathrm{W}\right)\end{array}$ & 11 & $2-2.9$ & 2.3 & 0.3 \\
\hline Sediment & $\begin{array}{l}\text { Port Foster, Deception Island }\left(62^{\circ} 55^{\prime} \mathrm{S}, 60^{\circ} 37^{\prime} \mathrm{W}\right) \text {; Macchu Picchu station } \\
\left(62^{\circ} 07^{\prime} \mathrm{S}, 58^{\circ} 23^{\prime} \mathrm{W}\right) \text {; Copacabana United States Refuge }\left(62^{\circ} 10^{\prime} \mathrm{S} \text {, }\right. \\
\left.58^{\circ} 26^{\prime} \mathrm{W}\right)\end{array}$ & 7 & $2-3.2$ & 2.4 & 0.4 \\
\hline Seawater & Botany point $\left(62^{\circ} 05^{\prime} \mathrm{S}, 58^{\circ} 19^{\prime} \mathrm{W}\right)$; Ulmann point $\left(62^{\circ} 05^{\prime} \mathrm{S}, 58^{\circ} 20^{\prime} \mathrm{W}\right)$ & 5 & $2-2.9$ & 2.1 & 0.2 \\
\hline $\begin{array}{l}\text { Freshwater from } \\
\text { lakes }\end{array}$ & $\begin{array}{l}\text { Macchu Picchu Station }\left(62^{\circ} 07^{\prime} \mathrm{S}, 58^{\circ} 23^{\prime} \mathrm{W}\right) \text {; Copacabana United States } \\
\text { Refuge }\left(62^{\circ} 10^{\prime} \mathrm{S}, 58^{\circ} 26^{\prime} \mathrm{W}\right)\end{array}$ & 16 & $2-3.7$ & 2.3 & 0.5 \\
\hline
\end{tabular}


Table 2. Identification of yeasts isolated from different substrates in Antarctica.

\begin{tabular}{|c|c|c|c|}
\hline UFMGCB code & Closest related species/GenBank accession numbers & Similarity $(\%)$ & Identification \\
\hline ANT 92 & Aureohasidium nullulans DBVPG 5028 / GO911487 & 100 & A. nullulans \\
\hline ANT 84.85 & Bensingtonia vamatoana CBS7243 / AF189896 & 99 & B. vamatoana \\
\hline ANT $28,22,33.37,44.108 .109$ & Candida glaebosa CBS 5691 / CGU45757 & 99 & C. glaebosa \\
\hline ANT 60.98 & Candida sake CBS 5740 / AY536216 & 100 & C. sake \\
\hline ANT 168 & Candida spencermartinsiae CBS 10894 / FJ008044 & 100 & C. spencermartinsiae \\
\hline ANT 130 & Candida zevlanoides CBS 619 / U45832 & 99 & C. zevlanoides \\
\hline ANT 21 & Crvptococcus antarcticus CBS7687 / A.F075488 & 99 & Cr. antarcticus \\
\hline $\begin{array}{l}\text { ANT } 29,35,53,56,77,97,100,102,103 \\
104,106,120,128, \text { MFA } 17\end{array}$ & Cryptococcus victoriae CBS 8884 / AF444741 & 99 & Cr. victoriae \\
\hline ANT 20.105.111. 112 & Debarvomvces hansenii NRRL Y-17914 / DHU94927 & 99 & D. hansenii \\
\hline ANT 76 & Dioszegia aurantiaca PYCC 5856 / AY562141 & 99 & D. aurantiaca \\
\hline ANT 68 & Dioszesia crocea CBS 6714 / AF075508 & 99 & D. crocea \\
\hline ANT 73. EACF 103 & Dioszegia hungarica CBS 5124 / AF314231 & 99 & D. hungarica \\
\hline ANT 99 & Dioszegia sp. CRUB 1147 / EF595753 & 98 & Dioszegia sp. \\
\hline ANT 126. 141. 145. 149 & Exophialla xenobiotica CBS 115831 / FJ358246 & 99 & E. xenobiotica \\
\hline ANT 39 & Filobasidium capsuligenum CBS 4381 / AF444695 & 94 & Filobasidium sp. \\
\hline MF 50 & Issatchenkia (Pichia) orientalis CBS 573 / AY497684 & 100 & I. orientalis \\
\hline MFA 14 & Kodamaea ohmeri ATCC 46053 / AF335976 & 100 & K. ohmeri \\
\hline ANT 24.62 .67 .80 & Leuconeurospora pulcherrima CBS 343.7 / AF096193 & 97 & Leuconeurospora sp. \\
\hline ANT 61.81 .91 .139 .170 & Leucosporidiella creatinivora CBS8620 / AF189925 & 99 & L. creatinivora \\
\hline ANT 30.69 .70 .71 .75 .78 & Leucosporidiella fragaria CBS 6254 / AF070428 & 99 & L. fragaria \\
\hline ANT 101.118 & Leucosporidiella muscorum CBS 6921 / AF070433 & 99 & L. muscorum \\
\hline ANT $63,133,158,160,166$. EACF 149 & Leucosporidium scottii CBS 5930 / AF070419 & 99 & L. scottii \\
\hline ANT 116.169 & Metschnikowia australis NRRL Y-7014 / U76526 & 100 & M. australis \\
\hline ANT 96b. 142.150 .152 & Microglossum rufum AFTOL 1292 / DO470981 & 92 & Microglossum sp.1 \\
\hline ANT 146 & Microglossum rufum AFTOL 1292 / DO470981 & 89 & Microglossum sp. 2 \\
\hline ANT 50.54 & Nadsonia commutata CBS 6640 / U73598 & 100 & N. commutata \\
\hline MF 36 & Pichia guilliermondii CBS 2030 / U45709 & 99 & P. guilliermondii \\
\hline ANT 117.121 .122 .123 & Rhodotorula glacialis DBVPG 4797 / EF643740 & 99 & Rh. glacialis \\
\hline ANT 11.131 .136 & Rhodotorula larvneis CBS 2221 / AF189937 & 99 & Rh. larvneis \\
\hline ANT 153. MFC14 & Rhodotorula mucilaginosa Y-17501 / AF189951 & 99 & Rh. mucilaginosa \\
\hline ANT 86 & Snorodiobolus salmonicolor CBS 490 / AF070439 & 99 & S. salmonicolor \\
\hline
\end{tabular}


Table 3. Yeast species isolated from different sources in Antarctica.

\begin{tabular}{|c|c|c|c|c|c|c|c|c|c|c|c|c|c|c|}
\hline \multirow{2}{*}{ Identification } & \multicolumn{14}{|c|}{ Origin of isolates } \\
\hline & $\mathbf{A}(\mathbf{n}=\mathbf{2 1})^{\mathrm{a}}$ & $\mathbf{B}(\mathbf{n}=\mathbf{1})$ & $C(n=7$ & $D(n=1)$ & $\mathbf{E}(\mathbf{n}=\mathbf{3}$ & $F(n=6$ & $G(n=1)$ & $\mathbf{H}(\mathbf{n}=\mathbf{1})$ & $I(n=4)$ & $J(n=2)$ & $K(n=2)$ & $\mathbf{L}(\mathbf{n}=\mathbf{3})$ & $M(n=11)$ & $N(n=5)$ \\
\hline Aureobasidium pullulans & - & - & - & - & - & - & - & - & - & - & - & - & - & 1 \\
\hline Bensingtonia yamatoana & - & - & 1 & - & 1 & - & - & - & - & - & - & - & - & - \\
\hline Candida glaebosa & - & 1 & 3 & - & - & 2 & - & - & - & 1 & - & - & - & - \\
\hline C. sake & 2 & - & - & - & - & - & - & - & - & - & - & - & - & - \\
\hline C. spencermartinsiae & - & - & - & - & - & - & - & - & - & - & - & 1 & - & - \\
\hline C. zeylanoides & - & - & - & - & - & - & - & - & - & - & 1 & - & - & - \\
\hline Cryptococcus antarcticus & 1 & - & - & - & - & - & - & - & - & - & - & - & - & - \\
\hline Cr. victoriae & 7 & 1 & 2 & - & - & 1 & - & - & 1 & - & - & - & 1 & 1 \\
\hline Debaryomyces hansenii & 1 & - & - & - & - & 3 & - & - & - & - & - & - & - & - \\
\hline Dioszegia aurantiaca & 1 & - & - & - & - & - & - & - & - & - & - & - & - & - \\
\hline D. crocea & 1 & - & - & - & - & - & - & - & - & - & - & - & - & - \\
\hline D. hungarica & 2 & - & - & - & - & - & - & - & - & - & - & - & - & - \\
\hline Dioszegia sp. & 1 & - & - & - & - & - & - & - & - & - & - & - & - & - \\
\hline Exophiala xenobiotica & - & - & - & - & - & - & - & - & - & - & - & - & - & 4 \\
\hline Filobasidium sp. & - & - & - & 1 & - & - & - & - & - & - & - & - & - & - \\
\hline Issatchenkia (Pichia) orientalis & - & - & - & - & - & - & - & - & - & - & - & - & 1 & - \\
\hline Kodamaea ohmeri & - & - & - & - & - & - & - & - & - & - & - & - & 3 & - \\
\hline Leuconeurospora sp. & 2 & - & 1 & - & 1 & - & - & - & - & - & - & - & - & - \\
\hline Leucosporidiella creatinivora & 1 & - & - & - & 1 & - & - & - & - & - & - & 2 & - & 1 \\
\hline L. fragaria & 5 & - & 1 & - & - & - & - & - & - & - & - & - & - & - \\
\hline L. muscorum & 1 & - & - & - & - & - & - & - & 1 & - & - & - & - & - \\
\hline Leucosporidium scottii & - & - & - & - & - & - & 1 & - & - & - & 2 & 3 & - & - \\
\hline Metschnikowia australis & - & - & - & - & - & - & - & - & 1 & - & - & 1 & - & - \\
\hline Microglossum sp. 1 & - & - & - & - & - & - & - & - & - & - & - & - & - & 4 \\
\hline Microglossum sp. 2 & - & - & - & - & - & - & - & - & - & - & - & - & - & 1 \\
\hline Nadsonia commutate & - & - & 1 & - & - & - & - & - & - & 1 & - & - & - & - \\
\hline Pichia guilliermondii & - & - & - & - & - & - & - & - & - & - & - & - & 1 & - \\
\hline Rhodotorula glacialis & - & - & - & - & - & - & - & - & 4 & - & - & - & - & - \\
\hline Rh. laryngis & - & - & - & - & - & - & - & 1 & - & - & 2 & - & - & - \\
\hline Rh. mucilaginosa & - & - & - & - & - & - & - & - & - & - & - & - & 3 & 1 \\
\hline Sporidiobolus salmonicolor & - & - & - & - & - & - & - & - & - & - & - & - & - & 1 \\
\hline Total of isolates & 26 & 2 & 9 & 1 & 3 & 6 & 1 & 1 & 7 & 2 & 4 & 7 & 9 & 11 \\
\hline
\end{tabular}


We recovered Cryptococcus antarcticus, Cr. victoriae, Dioszegia hungarica, and Leucosporidium scottii, which are reported psychrophilic yeasts from Antarctica (40). According to Ruisi et al. (34) the majority of yeasts present in Antarctic habitats are psychrotolerants, and others are psychrophiles. The preponderance of psychrotolerance is probably a response to the wide temperature fluctuations in Antarctica that allows microorganisms to survive in unstable environments (29).

Cryptococcus victoriae was the most frequently identified species in our study. It was isolated from seven substrates, and most isolates were obtained from the rhizosphere of $D$. antarctica. It was also isolated from penguin guano, soil, sediment and freshwater samples. Cryptococcus victoriae was originally described from Antarctica, but some occurrences were recorded in Portuguese seawater as well as in the roots of Puccinela distans and Atriplex sagittata and spores of arbuscular mycorrhizal fungi collected in Germany (31, 40). The occurrence of $C r$. victoriae in the rhizosphere of $D$. antarctica and roots of temperate plant species suggests that this yeast may prefer the rhizosphere of plants in cold and temperate ecosystems.

Leucosporidium scottii was isolated only from seawater (Table 3). This yeast inhabits low-temperature environments, mostly polar or temperate regions during cold seasons (12). Although the isolates were obtained from seawater in this study, this species is considered to have a widespread distribution and occupy different substrates.

The ascomycetous yeast Metschnikowia australis is indigenous to Antarctic seawater (11), and we isolated it from marine sediment and seawater (Table 3). Metschnikowia australis was the predominant yeast species associated with the thalli of the algal species Adenocystis utricularis, Desmarestia anceps, and Palmaria decipiens in Antarctica (23). These algal thalli were reported as a new habitat for $M$. australis. Therefore, its isolation from seawater substrates in our study suggests a widespread distribution in Antarctica. The rare yeast Nadsonia commutata was isolated from penguin guano soil and seawater sediment. This species was discovered in soil from East Falkland Island in the Atlantic Ocean and from soil in the Carpathian Mountains of Eastern Europe (15). Nadsonia commutata has a low maximum growth temperature $\left(22-27^{\circ} \mathrm{C}\right)$ and is considered to be a psychrophilic yeast (25). This is the first report of its occurrence in Antarctica.

Four isolates of $R h$. glacialis were obtained from marine sediments of the Machu Picchu Station. This yeast is a true psychrophilic species and was originally isolated from alpine glacier cryoconite and mud in a thawing zone on the Stubaier Glacier near Innsbruck in Tyrol, Austria (24). This species was also isolated from subglacial and meltwater glacier sediments in Italy (38). The maximum growth temperature of the type strain of this species is $20^{\circ} \mathrm{C}$. However, two isolates in our study were able to grow at $25^{\circ} \mathrm{C}$.

Several cosmopolitan yeast species including A. pullulans, C. zeylanoides, D. hansenii, I. orientalis, $K$. ohmeri, $P$. guilliermondii, Rh. mucilaginosa, and S. salmonicolor were isolated (Table 3). Most of these mesophilic yeasts were isolated at low frequency in water samples and could represent immigrants carried by water or result from human presence in Antarctica.

In this work, some yeast isolates showed more than $1 \%$ nucleotide differences in the D1/D2 domains of the rRNA gene compared with the most closely related known species and thus could represent novel taxa. The isolate identified as Filobasidium sp. (UFMGCB-ANT39, GenBank access number HQ184184) had 20 substitutions compared to its closest related species, F. capsuligenum. The isolate identified as Dioszegia sp. had almost identical sequences to strain Dioszegia sp. CRUB 1147, which was isolated from altitudinal lakes in Argentina. The Antarctic and Argentinean isolates probably represent a new species closely related to Dioszegia hungarica. Four yeast-like isolates had $97 \%$ similarity (10 nucleotide differences and 5 gaps) compared with the type strain Leuconeurospora pulcherrima CBS 343.7 (GenBank accession

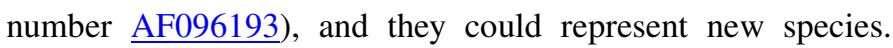


These strains were identified as Leuconeurospora sp. (UFMGCB-ANT62, GenBank access number HQ184181). The yeast-like fungal species identified as Microglossum sp. 1 (UFMGCB-ANT96b, GenBank access number HQ184182) and Microglossum sp. 2 (UFMGCB-ANT96b, GenBank access number HQ184183) had 92\% (36 nucleotide differences and 10 gaps) and 89\% (43 nucleotide differences and 20 gaps) similarity, respectively, compared with Microglossum rufum AFTOL 1292 (DQ470981). Microglossum sp. 1 differed from Microglossum sp. 2 by nine nucleotides in the D1/D2 domains of the rRNA gene, and both were considered to be two new, distinct species.

\section{Extracellular enzymatic activity}

Activity of at least a single extracellular enzyme was detected in 58 isolates $\left(60 \%\right.$ of total yeast isolates) at either 4 or $20^{\circ} \mathrm{C}$ (Table 4). Cellulolytic and esterase activities were most frequent and were present in $76 \%$ of isolates. Significantly higher levels of Tween 80 hydrolysis $(\mathrm{t}=3.1461 ; p=0.00192)$ were observed at $4^{\circ} \mathrm{C}$ compared to $20^{\circ} \mathrm{C}$. No significant differences between temperatures were observed for the other tested enzymatic activities. Most $\mathrm{Cr}$. victoriae isolates were able to hydrolyze Tween 80 and cellulose at 4 and $20^{\circ} \mathrm{C}$, most of which were isolated from the rhizosphere of D. antarctica. Most L. scottii isolates could hydrolyze protease and pectinase at $\mathrm{pH} 7$. Furthermore, most of the isolated yeasts were able to hydrolyze the compounds tested at low temperatures, providing further evidence of their metabolic adaptation to cold environments.

\section{Production of photoprotective compounds}

In this study, isolates belonging to the Tremellales group, including the pigmented species Dioszegia aurantiaca, D. crocea, D. hungarica and Dioszegia sp. and the non-pigmented species $\mathrm{Cr}$. antarcticus, were mycosporine-positive (Table 4). All of the isolates were obtained from the rhizosphere of $D$. antarctica. Libkind et al. (22) detected mycosporine production in Dioszegia species isolated from lakes in the Patagonian Mountains, which can be explained by the high-altitude and exposure to high UV radiation. All $\mathrm{Cr}$. victoriae isolates, also belonging to the
Tremellales group, were mycosporine-negative. Exophiala xenobiotica and Rh. laryngis also produced mycosporines. Organisms that can synthesize UV-protective compounds can occupy a great diversity of habitats (34), especially those habitats exposed to high UV radiation (22) such as in this work. The ascomycetous yeast-like fungi Microglossum sp. 1 and Microglossum sp. 2 also produced mycosporines. This report is the first of mycosporine-positive yeast-like ascomycetous species in Antarctic environments.

Twelve isolated species produced carotenoids or other pigments. Pigment production is a strategy to survive the stressful conditions of Antarctica. Although it does not produce mycosporines, the ubiquitous species $R$. mucilaginosa enhances UV-B survival by producing the carotenoid pigment torularhodin (27). In our study, $41.7 \%$ of the isolated yeasts were able to produce pigments and/or mycosporines and thus could be considered adapted to survive in Antarctica. In addition, most of the yeast isolates had extracellular enzymatic activities at both temperatures tested, indicating that they may be metabolically active in the sampled substrates.

\section{ACKNOWLEDGEMENTS}

This study was made possible with financial and logistical support from the Brazilian Antarctic Program (PROANTAR). It is part of the API activity 403 "MIDIAPI Microbial Diversity of Terrestrial and Maritime ecosystems in Antarctic Peninsula" under the coordination of Dr. Vivian H. Pellizari, and contributes to the umbrella IPY activities of MERGE (Microbiological and Ecological Responses to Global Environmental Changes in Polar Regions), CAML (Census of Antarctic Marine Life) and SCARMarBIN (SCARMarine Biodiversity Information Network). This work was also supported by Fundação do Amparo a Pesquisa do Estado de Minas Gerais (FAPEMIG), Coordenação de Aperfeiçoamento de Pessoal de Nível Superior (CAPES), Conselho Nacional de Desenvolvimento Científico e Tecnológico (CNPq), Universidad Nacional del Comahue (B143) and ANPCyT Argentina (PICT 1176). 
Table 4. Extracellular enzymatic activity, mycosporine and pigment production of yeasts from Antarctica.

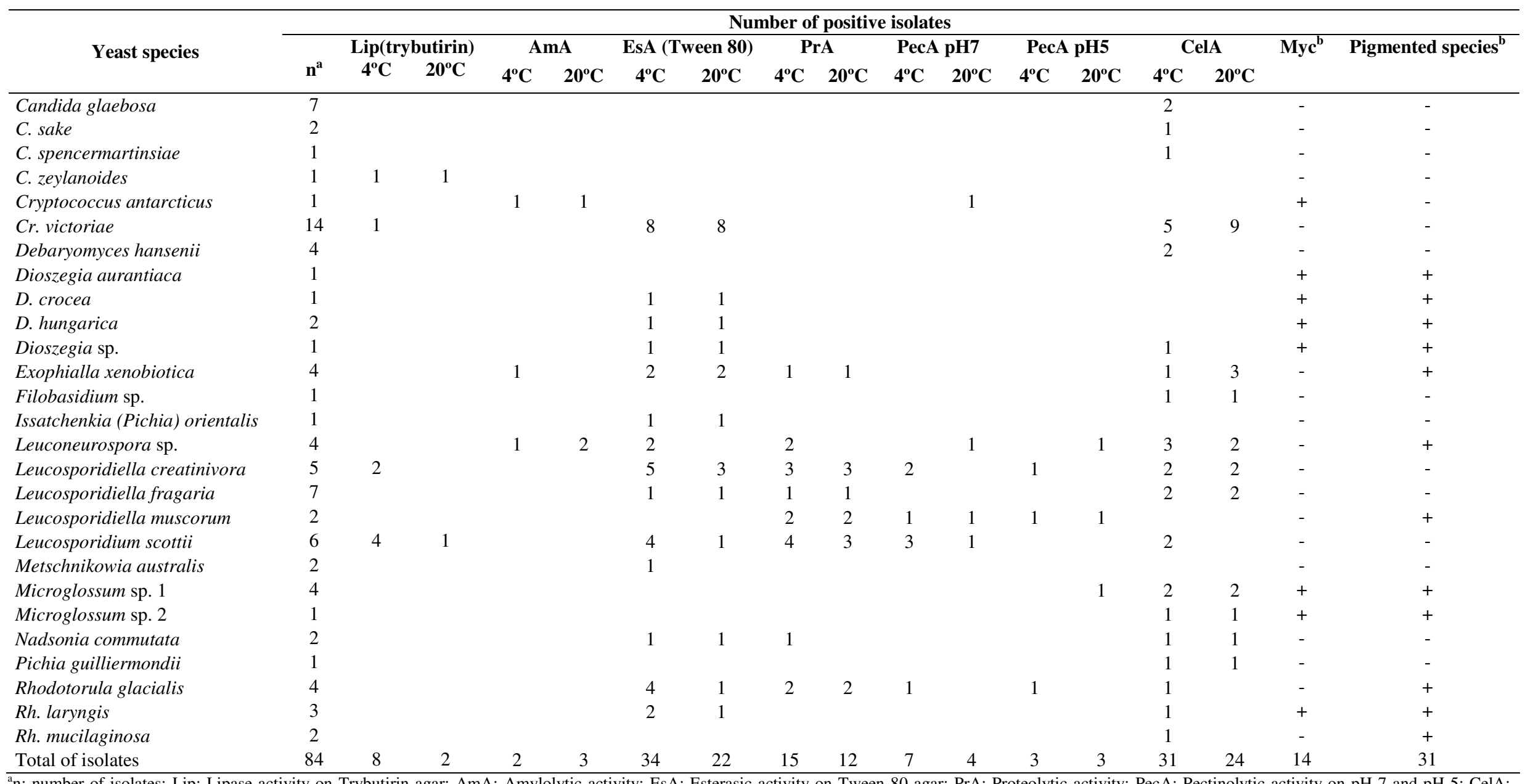

${ }^{a}$ n: number of isolates; Lip: Lipase activity on Trybutirin agar; AmA: Amylolytic activity; EsA: Esterasic activity on Tween 80 agar; PrA: Proteolytic activity; PecA: Pectinolytic activity on pH 7 and pH 5; CelA: Cellulolytic activity; Myc:Mycosporine; +: positive; -: negative.

${ }^{\mathrm{b}}$ All isolates belonging to a species with + result were positive for the character. 


\section{REFERENCES}

1. Amato, P.; Doyle, S.; Christner, B. C. (2009). Macromolecular synthesis by yeasts under frozen conditions. Environ. Microbiol. 11 (3), 589-596.

2. Adams, B.J.; Richard, D.; Bardgettb, Ayresc, E.; Wallc, D.H.; Aislabied, J.; Bamforthe, S.; Bargaglif, R.; Caryg, C.; Cavacinih, P.; Connelli, L.; Conveyj, P.; Fellk, J.W.; Fratil, F.; Hoggm, I.D.; Newshamj, K.K.; O’Donnelln, A.; Russello, N.; Seppeltp, R.D.; Stevensq, M. I. (2006). Diversity and distribution of Victoria Land biota. Soil Biol. Bioch. 38 (10), 3003-3018.

3. Altschul, S.; Madden, T.; Schaffer, A.; Zhang, J.; Zhang, Z.; Miller, W.; Lipman, D. (1997). Gapped BLAST and PSI-BLAST: a new generation of protein database search programs. Nucleic Acids Res. 25 (17), 33893402.

4. Botha, A. (2006). Yeast in Soil. In: Rosa, C. A., Gárbor, P. (eds.) Biodiversity and Ecophysiology of Yeast. Springer-Verlag, Berlin Heidelberg, p. 221-240.

5. Brizzio, S.; Turchetti, B.; de García, V.; Libkind, D.; Buzzini, P.; van Broock, M. (2007). Extracellular enzymatic activities of basidiomycetous yeasts isolated from glacial and subglacial waters of northwest Patagonia (Argentina). Can. J. Microbiol. 53 (4), 519-25.

6. Bridge, P.D.; Spooner, B.M.; Roberts, P.J. (2008). List of NonLichenized Fungi from the Antarctic region (Version 2.3.1; April 2008). http://www.antarctica.ac.uk//bas_research/data/access/fungi/ (accessed September 2008).

7. Connell, L.; Redman, R.; Craig, S.; Rodriguez, R. (2006). Distribution and abundance of fungi in the soils of Taylor Valley, Antarctica. Soil Biol. Bioch. 38 (10), 3083-3094.

8. Cowan, D.A.; Tow L.A. (2004). Endangered Antarctic Environments. Annu. Rev. Microbiol. 58, 649-690.

9. de García, V.; Brizzio, S.; Libkind, D.; Buzzini, P.; van Broock, M. (2007). Biodiversity of cold-adapted yeasts from glacial meltwater rivers in Patagonia, Argentina. FEMS Microbiol. Ecol. 59 (2), 331-341.

10. di Menna, M.E. (1966). Yeasts in Antarctic soils. Antonie van Leeuwenhoek 32 (1), 2938.

11. Fell, J.W.; Hunter, I.L. (1968). Isolation of heterothallic yeast strains of Metschnikowia Kamienski and their mating reaction with Chlamydozyma wickerham. Antonie van Leeuwenhoek 34 (3), 365-376.

12. Fell, J.W.; Statzell, A.C.; Hunter, I.L.; Phaff, H.J. (1969). Leucosporidium gen.nov., the heterobasidiomycetous stage of several yeasts of the genus Candida. Antonie van Leeuwenhoek 35 (1), 433-462.

13. Fell, J.W.; Scorzetti, G.; Connell, L.; Craig, S. (2006). Biodiversity of micro-eukaryotes in Antarctic Dry Valley soils with 5\% soil moisture. Soil Biol. Bioch. 38 (10), 3107-3119.

14. Gadanho, M.; Sampaio, J.P. (2002). Polyphasic taxonomy of the basidiomycetous yeasts genus Rhodotorula: $R$. glutinis sensu stricto and R. dairenensis comb. nov. FEMS Yeast Res. 2 (1), 47-58.
15. Golubev, W.I.; Smith, M.T.; Poot, G.A.; Kock, J.L.F. (1989). Species delineation in the genus Nadsonia sydow. Antonie van Leeuwenhoek 55 (4), 369-382.

16. Kumar, S.; Tamura, K.; Jakobsen, I.B.; Nei, M. (2001). MEGA 2: Molecular Evolutionary Genetics Analysis software, Arizona State University, Tempe, AZ, USA.

17. Kurtzman, C.P.; Fell, J.W. (1998). The yeasts, a taxonomic study. Elsevier Science Publishers, Amsterdam, the Netherlands.

18. Lachance, M.A.; Starmer, W.T. (1998). Ecology and yeasts. In: Kurtzman, C.P., Fell, J.W. (eds). The Yeasts, a taxonomic study. Elsevier Science, Amsterdam, p. 21-30.

19. Lachance, M-A.; Bowles, J.M.; Starmer, W.T.; Barker, J.S. (1999). Kodamaea kakaduensis and Candida tolerans, two new ascomycetous yeast species from Australian Hibiscus flowers. Can. J. Microbiol. 45 (2), 172-177.

20. Libkind, D.; Brizzio, S.; Ruffini, A.; Gadanho, M.; van Broock, M.; Sampaio, P. (2003). Molecular characterization of carotenogenic yeasts from aquatic environments in Patagonia, Argentina. Antonie van Leeuwenhoek 84 (4), 313-322.

21. Libkind, D.; Sommaruga, R.; Zagarese, H.; van Broock, M. (2005). Mycosporines in carotenogenic yeasts. Syst. Appl. Microbiol. 28 (8), 749-754.

22. Libkind, D.; Moliné, M.; Sampaio, J. P.; Van Broock, M. (2009). Yeasts from high-altitude lakes: influence of UV radiation. FEMS Microbiol. Ecol. 69 (3), 353-362.

23. Loque, C.P.; Medeiros, A.O.; Pellizzari, F. M.; Oliveira, E.C.; Rosa, C.A.; Rosa, L.H. (2010). Fungal community associated with marine macroalgae from Antarctica. Polar Biol. 33 (5), 641-648.

24. Margesin, R.; Fonteyne, P. A.; Schinner, F.; Sampaio, J. P. (2007). Novel psychrophilic basidiomycetous yeasts from Alpine environments: Rhodotorula psychrophila sp. nov., Rhodotorula psychrophenolica sp. nov. and Rhodotorula glacialis sp. nov. Int. J. Syst. Evol. Microbiol. 57 (9), 2179-2184.

25. Miller, M.W.; Phaff, H. J. (1998). Metschnikowia kamienski. In: Kurtzman C. P., Fell. J. W. (eds). The Yeasts, a taxonomic study. Amsterdam, Elsevier, p. 256-267.

26. Moliné, M.; Libkind, D.; Diéguez, M.C.; van Broock, M. (2009). Photoprotective role of carotenoid pigments in yeasts: experimental study contrasting naturally occurring pigmented and albino strains. $J$. Photochem. Photobiol. B. 95 (3):156-161.

27. Moliné, M.; Regina Flores, M.; Libkind, D.; Diéguez, M.C.; Farías, M.E. \& van Broock, M. (2010a). Photoprotection by carotenoid pigments in the yeast Rhodotorula mucilaginosa: the role of torularhodin Photochem. Photobiol. Sci. 9 (8), 1145-1151.

28. Moliné, M.; Arbeloa, E. M.; Regina Flores, M.; Libkind, D.; M.C.; Farías, M.E.; Bertolotti, S.G.; Churio, M.S. \& van Broock, M. UV-B photoprotective role of mycosporines in yeasts: photostability and 
antioxidant activity of mycosporine-glutaminol-glucoside. Rad. Res. In press.

29. Onofri, S., Selbmann, L., Zucconi, L. and Pagano, S. (2004). Antarctic microfungi as models for exobiology. Planet Space Sci. 52 (1-3), 229237.

30. Phaff, H.J., Starmer, W.T. (1987). Yeasts associated with plants, insects and soils. In: Rose A.H., Harrison, J.S. (eds). The yeasts biology. Academic London, p. 123-180.

31. Renker, C.; Zobel, M.; Öpik, M.; Allen, M.F.; Allen, E.B.; Vosátka, M.; et al. (2004) Structure, dynamics, and restoration of plant communities: do arbuscular mycorrhizae matter? In: Temperton, V.M., Hobbs, R.J., Nuttle, T., Halle, S. (eds). Assembly Rules and Restoration Ecology Bridging the Gap between Theory and Practice. Washington, DC, USA: Island Press, p. 189-229.

32. Rosa, L.H.; Vaz, A.B.M.; Caligiorne, R.B.; Campolina, S.; Rosa, C.A. (2009). Endophytic fungi associated with the Antarctic grass Deschampsia antarctica Desv. (Poaceae). Polar Biol. 32 (2), 161-167.

33. Rosa, L.H.; Almeida, M.L.; Santiago, I.F.; Rosa, C.A. (2010). Endophytic fungal community associated with the dicotyledonous plant Colobanthus quitensis (Kunth) Bartl. (Caryophyllacea) in Antarctica. FEMS Microbiol. Ecol. 73 (1), 178-189.

34. Ruise, S.; Barreca, D.; Selbmann, L.; Zucconi, L.; Onofri, S. (2007). Fungi in Antarctica. Rev. Environ. Sci. Biotechnol. 6 (1-3), 127-141.

35. Sampaio, J.P.; Gadanho, M.; Santos, S.; Duarte, F.L.; Pais, C.; Fonseca, A.; Fell, J.W. (2001). Polyphasic taxonomy of the basidiomycetous yeasts genus Rhodosporidium: Rhodosporidium kratochvilovae and related anamorphic species. Int. J. Syst. Evol. Microbiol. 51 (2), 687-
697.

36. Thomas-Hall, S.; Watson, K.; Scorzetti, G. (2002). Cryptococcus statzelliae sp. nov. and three novel strains of Cryptococcus victoriae, yeasts isolated from Antarctic soils. Int. J. Syst. Evol. Microbiol. 52 (6), 2303-2308.

37. Thomas-Hall, S.R.; Turchetti, B.; Buzzini, P.; Branda, E.; Boekhout, T.; Theelen, B.; Watson, K. (2010). Cold-adapted yeasts from Antarctica and the Italian Alps-description of three novel species: Mrakia robertii sp. nov., Mrakia blollopis sp. nov. and Mrakiella niccombsii sp. nov. Extremophiles. 14 (1), 47-59.

38. Turchetti, B.; Buzzini, P.; Goretti, M.; Branda, E.; Diolaiuti, G.; D’Agata, C.; Smiraglia, C.; Vaughan-Martini, A. (2008). Psychrophilic yeasts in glacial environments of Alpine glaciers. FEMS Microbiol. Ecol. 63 (1), 73-83.

39. Vaz, A.B.M.; Mota, R.C.; Bomfim, M.R.Q.; Zani, C.L.; Rosa, C.A.; Rosa, L.H. (2009). Antimicrobial activity of endophytic fungi associated with Orchidaceae in Brazil. Can. J. Microbiol. 55 (12), 1381-1391.

40. Vishniac, H.S. (2006). Yeast biodiversity in the Antarctic. In: Rosa, C.A., Péter, G. eds. Biodiversity and ecophysiology of yeasts. SpringerVerlag, p. 221-240.

41. Yarrow, D. (1998). Methods for the isolation, maintenance and identification of yeast. In: Kurtzman, C.P., Fell, J.W. (eds). The Yeasts, a taxonomic study. Amsterdam, Elsevier, p. 77-100.

42. White, T.J.; Bruns, T.D.; Lee, S.B. (1989). Amplification and direct sequencing of fungal ribosomal RNA genes for phylogenetics. In: Innis, N.A., Gelfand, J., Sninsky, J., et al. (eds). PCR protocols: A guide to methods and applications. Academic Press, San Diego, p. 315-322. 